\title{
Dietary Selection and Nutrition of Spanish Goats as Influenced by Brush Management
}

\author{
EXPEDITO A. LOPES AND JERRY W. STUTH
}

\section{Abstract}

Botanical composition of Spanish goat diets was only different when diets selected from tebuthiuron-treated pastures were compared to those from untreated and mechanically treated areas in the Texas Post Oak Savannah. However, all brush management treatments significantly affected the browse component in summer diets. Diets selected from untreated and mechanically treated pastures were dominated by browse, while grasses and grasslike plants occurred most in diets selected from the tebuthiuron-treated plots. Yet, during fall and winter, vines comprised the bulk of diets collected on these areas. Forbs were a minor dietary component. Goat diets from untreated and mechanically treated pastures consistently shifted from browse to grasses and grasslike plants as seasons advanced. Selection of grasses and grasslike plants on tebuthiuron-treated pastures declined sharply from summer through winter and increased through spring. Similar but inverse trends occurred in respect to vines and browse. Mean levels of crude protein (CP) in diets selected by esophageally fistulated goats grazing chemically treated pastures were significantly greater than in diets from the other pastures in winter and spring. In summer and fall, dietary forage material from all pastures contained equivalent levels of crude protein. Dietary in vitro digestible organic matter (IVDOM) was higher in summer and winter from tebuthiuron-treated pastures compared to mechanically treated and untreated areas. In fall, diets from tebuthiuron-treated pastures were higher in IVDOM content than those from untreated ones but were similar to diets from mechanically treated pastures. However, in spring all pastures receiving brush management yielded diets with higher IVDOM content than brush-treated areas. In general, methods of brush control had greater effects on IVDOM than on $C P$ contents of diets.

Reduction of woody plant cover may be the primary step toward increasing forage production of depleted rangelands in Texas. The 2 most widely used approaches to brush management are mechanical methods and herbicide application (Scifres 1980). However, rising costs of fuel, equipment, and herbicides and lack of satisfactory control in some instances have stimulated interest in alternative control methods (Green et al. 1978).

Uplands and river bottoms in the Post Oak Savannah region of cast-central Texas were originally charactcrized as open savannah with a ground cover of mid and tall grasses (Smeins and Slack 1978). Yet, continued heavy yearlong grazing coupled with longterm fire suppression has led to range deterioration. As a result, millions of hectares now support dense thickets of brush which severely limit herbaceous forage production (Scifres and Haas 1974). Evaluation of cattle grazing practices in this region indicated that cattle will not maintain mechanically treated rangeland, or make efficient use of brush-infested areas (Kirby and Stuth

\footnotetext{
Authors are EMBRAPA (Brazilian Agriculture Research Institution) fellow and associate professor, Department of Range Science, Texas A\&M University, College Station 77843. Lopes is pesently coordinator of goat research, EMBRAPA/CNP-Caprinos, Sobral, Ceara, Brazil, 62.100

This article is published with the approval of the Director, Texas Agricultural Experiment Station, as TA-18090/.92.

Special appreciation is extended to Dr. Charles Scifres for his professional support and suggestions provided throughout this study.

Manuscript accepted February 29, 1984
}

1982a). A combination of cattle and goats might be used to effectively manipulate woody regrowth to sustain the beneficial aspects of mechanical treatments and maximize long-term returns.

Use of goats in many situations is perceived to be harmful to the environment. The goat controversy probably exists because of preconceived ideas and lack of reliable observations about this species. This unfortunately impedes a better understanding of its role in land use. The counterpart of the "maligned" image of goats is their capability to reduce brush cover on rangeland. Control of brush regrowth using goats following other brush treatments has shown good results in maintaining fuelbreaks in the southern California chaparral (Green et al. 1978), controlling brush species in Tanzania's Massailand (Martin and Huss 1981) and in the northern and central rangelands of Mexico (Fierro et al. 1980), and in reducing Gambel oak (Quercus gambelii) sprouts in Colorado (Davis et al. 1975). In western Texas, Spanish goats were useful in conjunction with prescribed burning for suppressing woody species during the growing season (Ueckert 1980).

The primary advantage of goats over other small ruminants lies in their multipurpose-utility. Since animal grazing preference is the major determinant factor in a grazing program (Davis et al. 1975), diet selection should be the first step in assessing the goat's potential as a complementary grazer and brush management agent. The primary objective of this study was to determine effects of brush management practices and season on botanical composition and nutritional content of Spanish goat's diets and browsing preference of goats for forage classes and plant species in Texas Post Oak Savannah.

\section{Materials and Methods}

The research area was located in the Post Oak Savannah, approximately $3 \mathrm{~km}$ west of College Station, Texas. The climate is subtropical with an average growing season of 274 days. Annual precipitation averages $94 \mathrm{~cm}$ with peaks in May and September. Mean temperature ranges from $10^{\circ} \mathrm{C}$ in January to $30^{\circ} \mathrm{C}$ in July (U.S. Department of Commerce 1975). Soils of the experimental pastures were sandy loams to fine sandy loams of the LufkinAxtel-Tabor series (Udertic paleustalfs, Scifres et al. 1981). Overstory vegetation was dominated by oaks (Quercus sp.). The principal woody species in the understory included yaupon (Ilex vomitoria), possumhaw yaupon (llex decidua), winged elm (Ulmus alata), gum bumelia (Bumelia lanuginosa), willow baccharis (Baccharis salinca), coralberry (Symphoricarpus orbiculatus), honeylocust (Gleditsia triacanthos), flameleaf sumac (Rhus copallina), sparkleberry (Vaccinium arboreum), Mexican plum (Prunus mexicana), Texas persimmon (Diospyros texana), eastern redcedar (Juniperus virginiana), and downy hawthorne (Crataegus mollis). Primary grass species were little bluestem (Schizachyrium scoparium). brownseed paspalum (Paspalum plicatulum), and Texas wintergrass (Stipa leuchotricha). Western ragweed (Ambrosia psilostachya), bitter sneezeweed (Helenium amarum), plantago (Plantago sp.), blackeyed susan (Rudbeckia divergens), croton (Croton sp.), southern thistle (Cirsium texanum), oxalis (Oxalis sp.), and throughwort weed (Eypatorium sp.) comprise the majority of forbs. Vines were saw greenbriar (Smilax bona-nox), southern dewberry 
(Rubus trivialis), and peppervine (Ampelopis arborea).

Two replications of the 3 treatments were fenced into equal units. Replication one pastures were $1.5 \mathrm{ha}$, while those of replication two were 2.5 ha in size. The brush management treatments were (1) untreated, (2) mechanical dozing and piling of underbrush and small trees in spring-summer 1977, and (3) aerial application of tebuthiuron $\mathrm{N}$-(5-(1,1-dimethyl-ethyl)-1,3-4 thiadiazol-2yl-N,Ndimethyl) urea at $2.2 \mathrm{~kg} /$ ha (active ingredient) as $20 \%$ pellets in May 1977

Availability of herbaceous vegetation was determined at the beginning of each of 4 seasonal collection periods. Herbaceous forage was clipped by species to ground level within 10 , randomly selected, $0.25-\mathrm{m}^{2}$ plots in each treatment pasture.

Browse species standing crop was determined by the crownvolume-weight technique described by Scifres et al. (1974). The point-centered quarter method (Cottam and Curtis 1956) was adapted for the basic evaluation method. Three, 30-point transects were established in each treatment pasture. The nearest browse plant encountered in each quarter of the point was visually appraised and assigned a geometric shape which best described the configuration of the canopy up to $1.5 \mathrm{~m}$ from the soil surface. The appropriate axil measurements for each geometric shape were made to determine the available canopy volume. Density was determined by species as described by Cottam and Curtis (1956). Ten, $27,000-\mathrm{cm}^{3}$ samples were then randomly selected each season from the outer canopy edge of each brush species to calculate weight of current year's growth per unit-volume $\left(\mathrm{g} / \mathrm{cm}^{3}\right)$ of available canopy. Utilizable canopy was delineated by the depth $(30 \mathrm{~cm})$ and height $(1.5 \mathrm{~m})$ to which the grazing animal could effectively penetrate the plant canopy under moderate stocking regimes. Browse availability $(\mathrm{kg} / \mathrm{ha})$ was derived by multiplying the average available canopy volume, the weight-volume factor $\left(\mathrm{g} / \mathrm{cm}^{3}\right)$, and the density (plant/ha) for each species.

Spanish goats with esophageal fistulae (Van Dyne and Torrel 1964) and fitted with removable cannulae as described by Taylor and Bryant (1977), were used to collect ingesta samples from each treatment pasture during summer (June 24 to July 3 ), fall (October 26 to November 5), winter (January 3 to 15), and spring (March 14 to 24) in 1980-81. An average of 10 animal-days of collections were made per treatment and replication over a 10-day samplng period across seasons. The fistulated goats were allowed to freely graze a given treatment pasture for 0.5 to 1.0 hour after overnight fasting. Extrusa was collected in screenbottomed bags during early morning and evening at least 3 times within the 10-day period.

Dietary material from each goat was thoroughly mixed, split into 2 subsamples for botanical and nutritional analysis, frozen for storage, and subsequently freeze-dried at $-50^{\circ} \mathrm{C}$ for 3 days. Nutrition subsamples were ground in a Wiley mill to pass a 1-mm screen.

Botanical composition of the diet samples by species was determined by the microscopic or macrofragment technique described by Kothmann et al. (1972) except that 15 randomly selected microplots per extrusa sample were used rather than 20 microplots. Extrusa-fragment percentages for each species in the diets were expressed on a weight basis (Rector and Huston 1982). Derived categories included grasses and grasslike plants, forbs, vine, browse and unidentifiable fragments.

A selectivity ratio (SR, Hodgson 1982) was calculated by season and treatment for each forb, vine, and browse species, and for the category, total grasses and grasslike plants. The formula described by Taylor et al. (1981) was used:

$$
\text { Selectivity ratio }=\frac{\% \text { diet }-\% \text { available in field }}{\% \text { diet }+ \text { available in field }} \times 10
$$

Ratings of +10 and -10 are maximum and minimum selectivity values, while -1 to 1 indicates selection in proportion to availability. Crude protein content $(\% \mathrm{~N} \times 6.25)$ was determined by the micro-Kjeldahl method (A.O.A.C. 1970) and expressed on an organic-matter basis. Digestible organic matter on an ash-free basis was determined by using the first stage of the in vitro technique of Tilley and Terry (1963), followed by neutral detergent analysis (Van Soest and Wine 1967) to complete the apparent digestibility estimation.

Grazing pressure was maintained by 6 open, fistulated cows in rotation through the treatment pastures each being grazed for 7 to 19 days and rested for 60 to 115 days. The 6 fistulated goats were rotationally grazed 2 treatment pastures behind the cows resulting in 7 to 19 days of rest prior to making ingesta collections.

Ingesta and nutritional data were sorted by season and analyzed to detect differences $(\alpha=0.05)$ among treatments using the General Linear Model (Barr and Goodnight 1979). Duncan's multiple range test was used to detect differences among significant treatment means (Steel and Torrie 1980).

\section{Results}

Woody species provided the bulk of available forage on untreated and mechanically treated pastures, whereas grasses and grasslike plants were the major forage component on the tebuthiuron-treated pastures, regardless of season (Fig. 1). However,

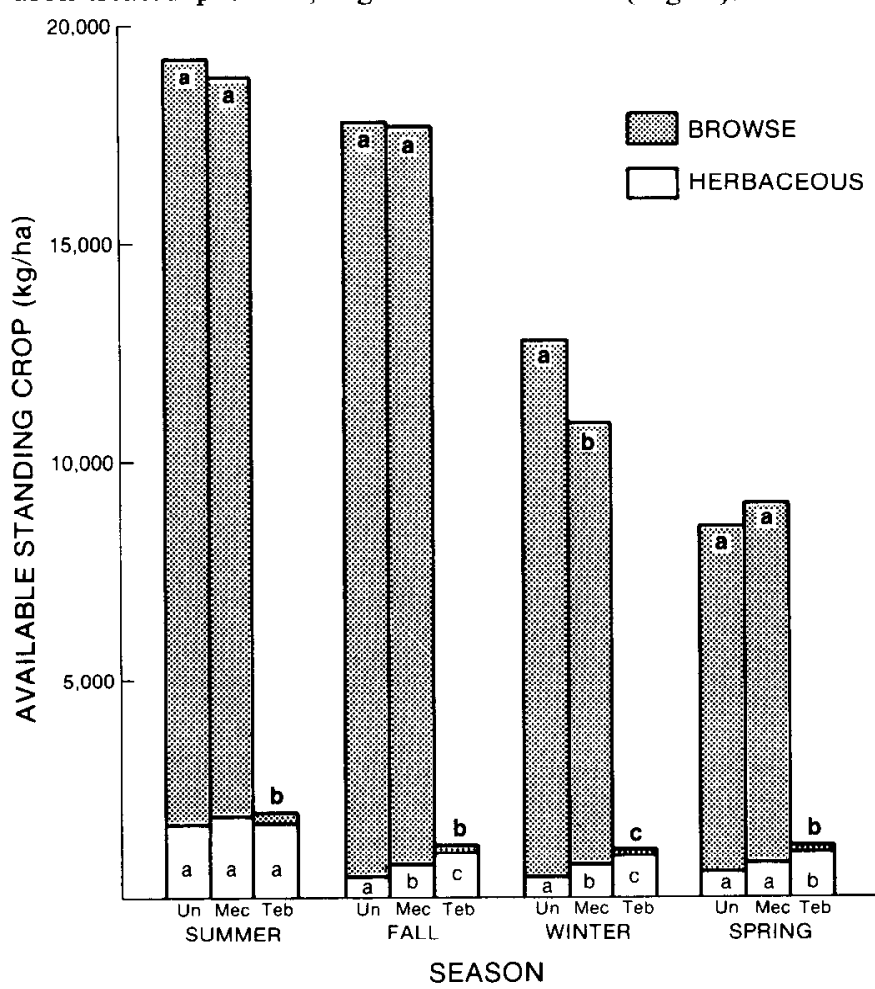

Fig. 1. Seasonal standing crop ( $\mathrm{kg} / \mathrm{ha}$ ) for browse and herbaceous (grasses and grasslike plants + forbs + vines) plant species on untreated (Un), mechanically treated (Mec) and tebuthiuron-treated (Teb) pastures in east central Texas. Bar sections within forage class with a common letter in a season are not significantly different $(\alpha=0.05)$.

absolute quantities of phytomass were several orders of magnitude lower on tebuthiuron-treated pastures than on others. Forbs and vines contributed least to total standing crop but were always more available on pastures treated with tebuthiuron than on the other pastures (Table 1). Oaks dominated the browse stands in all treatment pastures, followed by yaupons and willow baccharis (Table 1).

\section{Summer}

Percentages of browse in the diets differed significantly $(\alpha=0.05)$ among experimental pastures during summcr (Tablc 1). Browsc was the dominant dietary component on untreated and mechanically treated areas, comprising 77 to $51 \%$, respectively, of the goats' diets. Browse and forbs were minor components in goat diets on 
Table 1. Botanical composition (\%) by weight of forage stands in the field and in diets of Spanish goats following brush management ${ }^{1}$ in east-central Texas rangeland.

\begin{tabular}{|c|c|c|c|c|c|c|c|c|c|c|c|c|c|c|c|c|c|c|c|c|c|c|c|c|}
\hline & \multicolumn{12}{|c|}{ Composition on pastures ${ }^{2}$} & \multicolumn{12}{|c|}{ Composition in diets ${ }^{2}$} \\
\hline & \multicolumn{3}{|c|}{ Summer } & \multicolumn{3}{|c|}{ Fall } & \multicolumn{3}{|c|}{ Winter } & \multicolumn{3}{|c|}{ Spring } & \multicolumn{3}{|c|}{ Summer } & \multicolumn{3}{|c|}{ Fall } & \multicolumn{3}{|c|}{ Winter } & \multicolumn{3}{|c|}{ Spring } \\
\hline & Un & Mec & Teb & Un & Mec & Teb & Un & Mec & Teb & Un & Mec & Teb & Un & Mec & Teb & Un & $\mathrm{Mec}$ & Teb & Un & Mec & Teb & Un & $\mathrm{Mec}$ & $=\mathrm{Teb}$ \\
\hline \multicolumn{25}{|l|}{ Grass and grass- } \\
\hline like plants & $7 b$ & $9 b$ & $80 a$ & $2 b$ & $4 \mathrm{~b}$ & $84 a$ & $3 b$ & $5 b$ & $84 a$ & $4 b$ & $5 \mathrm{~b}$ & $71 a$ & $13 a$ & $18 \mathrm{a}$ & $64 b$ & $32 a$ & $25 \mathrm{a}$ & $30 \mathrm{a}$ & la & $\mathrm{t}$ & $12 \mathrm{~b}$ & $26 a$ & $25 \mathrm{a}$ & $57 b$ \\
\hline \multicolumn{25}{|c|}{ 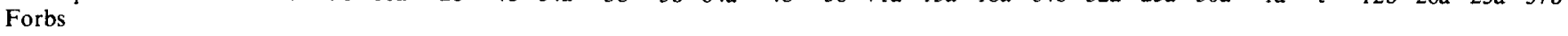 } \\
\hline Western ragweed & 1 & 1 & - & - & $\ldots$ & -- & - & $t^{3}$ & - & $\mathrm{t}$ & 1 & $2 a$ & $4 a$ & $t$ & la & $2 a$ & $2 a$ & - & & - & - & la & - & la \\
\hline Bitter sneezeweed & $\mathrm{t}$ & $\mathrm{t}$ & 13 & 一 & - & - & - & - & 1 & - & $i$ & 1 & $3 a$ & $6 a$ & $3 a$ & - & - & - & - & - & - & - & - & 1 \\
\hline Blackeyed susan & $\mathrm{t}$ & $\mathbf{t}$ & $\mathrm{t}$ & - & $\mathrm{t}$ & 2 & - & - & 1 & - & - & 1 & $\mathrm{t}$ & la & la & la & la & $2 \mathrm{a}$ & - & - & - & la & la & la \\
\hline Croton & $\mathrm{t}$ & $\mathrm{t}$ & $t$ & - & - & 1 & - & - & & $t$ & $t$ & - & $\mathrm{t}$ & $i$ & - & - & - & - & - & & - & - & - & \\
\hline Plantago & - & - & - & - & - & 1 & - & - & 1 & 1 & 1 & 7 & - & 一 & $t$ & $t$ & - & 7 & - & - & - & la & la & $4 b$ \\
\hline Southern thistle & - & - & - & - & - & 1 & - & $t$ & 2 & - & - & - & - & 一 & - & $\mathrm{t}$ & - & - & $\mathrm{t}$ & $t$ & $t$ & la & $4 b$ & $2 b$ \\
\hline Oxalix & - & - & - & - & - & 1 & - & - & 2 & - & - & 1 & - & - & 1 & la & la & $2 a$ & $\mathrm{t}$ & $t$ & $\mathrm{t}$ & - & la & la \\
\hline Throughwort weed & - & - & - & - & - & - & - & - & - & - & - & $i$ & - & - & - & - & - & - & - & - & - & - & - & 1 \\
\hline Unidentified & $\mathrm{t}$ & - & 1 & $t$ & $t$ & 2 & $t$ & $\mathrm{t}$ & 1 & lb & $2 b$ & $9 a$ & la & $2 \mathrm{a}$ & la & $2 a$ & $4 a$ & $3 a$ & $2 a$ & $2 a$ & $4 a$ & la & la & $4 a$ \\
\hline Total & $1 b$ & $1 b$ & $14 a$ & - & - & 8 & - & - & 8 & $2 b$ & $3 b$ & $20 \mathrm{a}$ & $6 a$ & $13 \mathrm{a}$ & $6 a$ & $5 a$ & $8 a$ & $16 \mathrm{~b}$ & $2 a$ & $2 a$ & $4 a$ & $5 a$ & $8 a$ & $15 b$ \\
\hline \multicolumn{25}{|l|}{ Vines } \\
\hline Saw greent & $\mathrm{t}$ & $\mathrm{t}$ & - & - & $\mathrm{t}$ & $\mathrm{t}$ & - & - & $\mathrm{t}$ & - & $t$ & 2 & $3 a$ & $17 b$ & $13 b$ & $7 \mathbf{a}$ & $6 a$ & $17 \mathrm{~b}$ & $8 \mathbf{a}$ & $8 a$ & $12 a$ & $2 a$ & $3 a$ & la \\
\hline Southern dewberry & $t$ & $\mathrm{t}$ & 1 & $\mathrm{t}$ & $\mathrm{t}$ & 1 & $\mathrm{t}$ & $t$ & 1 & 1 & 1 & 3 & la & $8 a$ & $9 \mathrm{a}$ & $13 \mathrm{ab}$ & $30 \mathrm{~b}$ & $14 a$ & & $14 a$ & $42 b$ & $13 \mathrm{a}$ & $21 \mathrm{a}$ & $16 \mathrm{a}$ \\
\hline Total & - & - & 1 & - & - & 1 & $\mathrm{t}$ & $\mathrm{t}$ & $i$ & 1 & 1 & 5 & $4 a$ & $18 b$ & $21 b$ & $16 a$ & $19 a$ & $47 \mathrm{~b}$ & $22 a$ & $22 a$ & $54 \mathrm{~b}$ & $15 \mathrm{a}$ & $24 a$ & $17 a$ \\
\hline \multicolumn{25}{|l|}{ Woody plants } \\
\hline Oaks & $49 b$ & $61 a$ & $2 c$ & $52 \mathrm{~b}$ & $66 a$ & $2 c$ & $34 a$ & $49 a$ & $\mathrm{lb}$ & $45 b$ & $63 a$ & lc & $39 a$ & $30 a$ & $2 b$ & $31 \mathrm{a}$ & $26 \mathrm{a}$ & $3 b$ & $10 \mathrm{a}$ & $22 b$ & la & $15 \mathrm{a}$ & $11 \mathrm{a}$ & $1 \mathrm{~b}$ \\
\hline Willow baccharis & $9 a$ & $5 a b$ & $2 b$ & $10 \mathrm{a}$ & $5 a b$ & $3 b$ & $15 \mathrm{a}$ & $9 \mathrm{ab}$ & $4 b$ & $7 \mathrm{a}$ & $4 a b$ & Ic & $\mathrm{t}$ & $t$ & 1 & $5 a$ & $7 a$ & $2 a$ & $30 \mathrm{a}$ & $38 \mathrm{~b}$ & $25 \mathrm{a}$ & $10 \mathrm{a}$ & $7 a$ & $9 a$ \\
\hline Coralberry & 1 & $\mathrm{t}$ & $\mathrm{t}$ & 1 & 2 & $\mathrm{t}$ & $\mathrm{t}$ & 1 & - & 2 & 1 & - & $9 a$ & $4 a$ & la & la & $2 a$ & - & $\mathrm{t}$ & - & - & la & la & - \\
\hline Gum bumelia & 2 & 1 & $\mathrm{t}$ & 2 & 1 & $\mathrm{t}$ & 2 & 1 & $\mathbf{t}$ & 3 & 2 & $t$ & $8 \mathbf{a}$ & $14 a$ & $\mathrm{t}$ & la & $3 a$ & $t$ & $\mathbf{t}$ & - & $t$ & $t$ & $t$ & $t$ \\
\hline Yaupons & $22 a$ & $19 \mathrm{a}$ & $1 b$ & $23 a$ & $20 a$ & Ib & $35 \mathrm{a}$ & $32 \mathrm{a}$ & $2 b$ & $25 a$ & $20 \mathrm{a}$ & lb & $4 a$ & la & - & $5 \mathbf{a}$ & $5 a$ & 1 & $30 a$ & $14 b$ & $4 b$ & $18 \mathrm{a}$ & $20 \mathrm{a}$ & Ib \\
\hline Winged elm & 8 & 1 & $\mathrm{t}$ & 8 & $\mathrm{t}$ & $\mathrm{t}$ & 10 & $t$ & $t$ & 6 & $t$ & $11 \mathrm{a}$ & $\mathrm{t}$ & $t$ & 1 & $\mathrm{t}$ & - & $\mathrm{t}$ & & - & $t$ & $6 a$ & la & - \\
\hline Honey locust & $\mathrm{t}$ & 1 & $\mathrm{t}$ & - & - & - & - & 1 & - & I & 1 & $\ldots$ & la & $1 \mathrm{a}$ & - & - & - & - & $\ldots$ & - & - & - & - & - \\
\hline Flameleaf sumac & $\mathrm{t}$ & $t$ & $\mathrm{t}$ & 1 & - & - & 1 & 1 & - & 1 & $t$ & 1 & 1 & $t$ & - & - & - & - & - & - & - & - & - & - \\
\hline Sparkleberry & 1 & 1 & - & - & 1 & - & - & - & t 1 & - & - & - & - & - & - & - & - & - & - & - & - & - & - & - \\
\hline Mexican plum & $\mathrm{t}$ & $\mathrm{t}$ & - & - & - & - & $\mathrm{t}$ & $t$ & $t$ & $\mathrm{t}$ & - & - & - & - & - & - & - & - & - & - & - & - & - & - \\
\hline Texas persimmon & $\mathrm{t}$ & 1 & - & - & 1 & - & - & $i$ & - & 2 & - & - & - & - & - & - & - & - & - & - & - & - & - & - \\
\hline Eastern redcedar & - & - & $t$ & 1 & - & I & $t$ & - & $\mathrm{t}$ & - & - & - & - & - & - & $t$ & - & - & $4 a$ & la & $\mathrm{t}$ & 1 & - & - \\
\hline Downy Hawthorne & $\mathrm{t}$ & $\mathrm{t}$ & - & - & - & - & - & - & - & - & - & - & - & - & - & - & - & - & - & - & - & - & - & - \\
\hline Unidentified & - & - & - & - & - & - & - & - & - & - & - & - & $4 a$ & la & $5 a$ & $3 a$ & $5 a$ & la & la & la & $\mathrm{t}$ & $3 a$ & $3 a$ & $\mathrm{t}$ \\
\hline Total & $92 a$ & $90 \mathrm{a}$ & $5 b$ & $98 a$ & $96 a$ & $7 b$ & $97 \mathbf{a}$ & $95 a$ & $7 b$ & $93 \mathbf{a}$ & $91 \mathrm{a}$ & $4 b$ & $77 a$ & $51 b$ & $9 \mathrm{c}$ & $47 a$ & $48 a$ & $7 b$ & $75 \mathrm{a}$ & $76 a$ & $30 b$ & $54 \mathrm{a}$ & $43 a$ & $11 \mathrm{~b}$ \\
\hline
\end{tabular}

'Brush treatments included: untreated (Un), mechanical (Mec) and tebuthiuron (Teb).

2Percentage values in rows within a season followed by the same letter are not significantly ( $\alpha=0.05$ ) different according to Duncan's Multiple Range Test. Indicates composition less than 0.5 .

tebuthiuron-treated pastures. Grasses and grasslike plants provided approximately $64 \%$ of the goat diets selected from the tebuthiuron-treated pastures and were present in significantly greater amounts than when the goats grazed untreated and mechanically treated pastures. Vines, mainly saw greenbriar, constituted one-fifth of the diet on the mechanical and tebuthiurontreated pastures where these plants had been released from competition in response to canopy removal.

Primary browse species were ranked as follows in goat diets on unt reated and mechanically dozed pasture during summer: oaks $>$ winged elm > yaupons > willow baccharis (Table 1). If browse availability was considered, then the selective order could be described as winged elm $>$ oaks $>$ yaupon $>$ willow baccharis (Table 2). Selectivity for saw greenbriar and southern dewberry was high during this period, particularly on the mechanically dozed and tebuthiuron-treated pastures.

Although goat diets from the untreated and mechanically treated pastures were comprised mainly of browse while diets from the tebuthiuron-treated pastures were grass dominated, dietary values of $\mathrm{CP}$ were similar across treatments averaging $10 \% \mathrm{CP}$. (Fig. 2). However, IVDOM in diets was the highest from tebuthiurontreated pastures during the summer period when compared to untreated and mechanically treated pastures (Fig. 3). The IVDOM value of goat diets from each treatment appeared to decrease with increasing a mounts of dietary browse. High dietary lignin content associated with cell walls of browse has been closely associated with lowered IVDOM in diets high in browse content.
Fall

Diets selected from the tebuthiuron-treated pastures during the fall differed significantly from those on other treatments for all classes of forage except for grasses and grasslike plants. All forage classes were similar in diets collected from untreated and mechanically trcated areas. Browse was the major dietary component on both treatments, accounting for approximately $50 \%$ of the forage consumed. However, on tebuthiuron-treated areas, browse dietary contribution was minor. Grasses and grasslike plants were consistently an important dietary constituent, regardless of the brush treatment, comprising 25 to $32 \%$ of the goat diets.

The proportion of vines in the diets were similar on untreated areas $(16 \%)$ and mechanically treated pastures $(20 \%)$. However, vines in diets of goats grazing the tebuthiuron-treated pastures $(47 \%)$ were greater $(\alpha=0.05)$. Forbs were highest in diets from the tebuthiuron-treated plots (16\%) compared with untreated and mechanically treated plots ( $5 \%$ and $8 \%$, respectively).

The browse component of diets on the untreated pastres declined by $40 \%$, relative to summer dietary levels, in the fall. Grasses and grasslike plants declined more than $50 \%$ on the tebuthiuron-treated plots from the summer to fall. Little variation in dietary compositon occurred between summer and fall for the mechanically treated pastures. Grasses and grasslike plants and vines replaced browse in the diets from summer to fall on the untreated pastures, and to some degree on the mechanically treated areas. Lush regrowth of grasses, grasslike plants, and vines was available on all pastures during the fall as a result of previous 
Table 2. Selectivity ratios for some key woody species, groups of species and classes of forage in Spanish goat diets selected from brush managed pastures in east-central Texas. ${ }^{1}$

\begin{tabular}{|c|c|c|c|c|c|c|c|c|c|c|c|c|}
\hline \multirow[b]{2}{*}{ Species/Class } & \multicolumn{3}{|c|}{ Summer } & \multicolumn{3}{|c|}{ Fall } & \multicolumn{3}{|c|}{ Winter } & \multicolumn{3}{|c|}{ Spring } \\
\hline & Un & Mec & $\overline{\text { Teb }}$ & Un & Mec & Teb & Un & Mec & Teb & Un & Mec & $\overline{\text { Teb }}$ \\
\hline \multicolumn{13}{|l|}{ Woody plants } \\
\hline Oaks & -1.1 & -3.4 & 0.0 & -2.5 & -4.3 & +2.0 & -5.5 & -3.8 & 0.0 & -5.0 & -7.0 & 0.0 \\
\hline Willow baccharis & -9.4 & -9.2 & -3.3 & -3.3 & +1.7 & -0.2 & +3.3 & +6.2 & +7.2 & +1.8 & +2.7 & +8.0 \\
\hline Coralberry & +8.0 & +8.9 & +6.6 & 0.0 & 0.0 & $-10.0^{2}$ & 0.0 & -10.0 & 3 & -3.3 & 0.0 & - \\
\hline Gum bumelia & +6.0 & +8.7 & +5.0 & -3.3 & +5.0 & 0.0 & -6.1 & -10.0 & 0.0 & -9.0 & -7.4 & 0.0 \\
\hline Yaupon & -6.9 & -8.7 & -10.0 & -6.4 & -6.0 & 0.0 & -0.8 & -3.9 & +6.0 & -1.6 & 0.0 & 0.0 \\
\hline Winged elm & +1.6 & +3.3 & 0.0 & -7.8 & +2.0 & -10.0 & -8.2 & -10.0 & +3.0 & 0.0 & +6.0 & -10.0 \\
\hline Eastern redcedar & - & - & - & - & - & - & +9.9 & $+10.0^{4}$ & +4.3 & +10.0 & - & - \\
\hline Total & -0.9 & -2.8 & +2.9 & -3.5 & -3.3 & 0.0 & -1.3 & -1.1 & +6.2 & -2.7 & -3.6 & +4.7 \\
\hline \multicolumn{13}{|l|}{ Vines } \\
\hline Saw greenbriar & 9.3 & +9.9 & +10.0 & +10.0 & +9.7 & +9.9 & +10.0 & +10.0 & +9.7 & +10.0 & +8.5 & -3.3 \\
\hline Southern dewberry & +8.2 & +8.8 & +7.8 & +9.8 & +9.7 & +9.4 & +9.9 & +9.6 & +9.5 & +8.6 & +9.1 & +6.8 \\
\hline Total & +9.0 & +9.8 & +9.1 & +9.9 & +9.7 & +9.5 & +9.7 & +9.7 & +9.6 & +8.8 & +9.2 & +5.5 \\
\hline Grasses and grasslike & & & & & & & & & & & & \\
\hline plants & +3.0 & +3.3 & -1.1 & +8.8 & +7.2 & +4.7 & -0.5 & -9.2 & -7.5 & -7.3 & +6.6 & -1.1 \\
\hline Forbs & +7.1 & +8.6 & -4.0 & +10.0 & +10.0 & +2.5 & +10.0 & +10.0 & -3.3 & +4.3 & +4.5 & -1.4 \\
\hline
\end{tabular}

'Selectivity ratios range from a maximum of +10 to a minimum of -10 with -1 to I being selection in proportion to availability. Brush treatments included: untreated (Un), mechanical (Mec) and tebuthiuron (Teb).

${ }^{2}$ Species were evident in clipped plots, but not in diets.

${ }^{3}$ Species were not evident in clipped plots or diets.

4 Species were not in clipped plots, but were identified in diets.

grazing by cattle and frequent rain showers. For example, during this collection period the study area received $13.6 \mathrm{~cm}$ precipitation over 30 days in 13 events. Decreased amounts of grasses and grasslike plants in the diets from the tebuthiuron-treated areas were replaced by vines, and to a lesser degree by forbs.

Primary browse species could be ranked in the diets of goats grazing during fall as: oaks $>$ willow baccharis $>$ yaupons $>$ winged elm. The following selective order is based on availability: willow baccharis $>$ oaks $>$ yaupon $>$ winged elm (Table 2). Winged elm and willow baccharis would replace yaupon and oaks in selective order during the fall period if available as sprouts. Mature winged elm plants dropped their leaves early in the fall while sprouts maintained green leaves into winter. Rapid senescence of older willow baccharis leaves during the period, coupled with their overlapping growth habit would tend to reduce selectivity of more mature or ungrazed plants.

Goats selected forage from all pastures in the fall, which averaged $12 \% \mathrm{CP}$. Although dietary CP was not different across treatments, the diets varied across treatments. The lack of browse in the tebuthiuron-treated pasture was compensated for by increased vine consumption, primarily southern dewberry. The greater consumption of grass, grasslike, and vines on the tebuthiuron-treated pastures resulted in higher IVDOM content in the goats' diets as compared to the greater browse-producing untreated pastures.

\section{Winter}

Amounts of browse in diets from all pastures increased during the winter, compared to amounts in fall diets. A similar trend existed for vines, though not as pronounced as with browse. The reverse occurred with herbs. Browse was the most important dietary constituent in the untreated pastures, contributing $75 \%$ to the diets, and approached the levels observed in summer. Willow baccharis and yaupon were the most important species in the diets, comprising $80 \%$ of the browse selected from untreated and mechanically treated pastures. Oaks in goat diets were represented by dead, fallen leaves. Grasses and grasslike plants declined to their lowest dietary levels across treatments in winter, approaching zero on untreated and mechanically treated pastures, whereas vines increased in the diets.

Vines were the major contributors to goat diets from the tebuthiuron-treated pastures during winter. Browse also was of importance in diets selected from these pastures, increasing from less than $10 \%$ during fall to approximately $30 \%$ in winter. More than $78 \%$ of the vine and browse components in diets resulted from ingestion of southern dewberry and willow baccharis on the chemically treated pastures. Grasses and grasslike plants consumed on these pastures during winter were comprised apparently of green regrowth of brownseed paspalum (Paspalum plicatulum).

Primary browse species were ranked in the diets of goats in winter as: willow baccharis $>$ yaupon $>$ oaks $>$ winged elm. If availability was considered, selective order was: willow baccharis $>$ yaupon $>$ oaks $>$ winged elm (Table 2 ). Willow baccharis was readily consumed during winter while yaupon was consumed in proportion to its availability. Substantial grazing on oaks and winged elm would require forced consumption, since oaks and winged elm lose most of their leaves during the winter period.

CP and IVDOM content of goat diets selected from tebuthiurontreated pastures was greater than in these diets from untreated and mechanically treated pastures during the winter. The higher quality diets from the tebuthiuron-treated pastures was associated with a greater consumption of cool-season annual grasses, regrowth of perennial grasses and southern dewberry leaves with a respective reduction in browse consumption as compared to diets from the other pastures.

A greater CP content in diets in winter as compared to fall differs from the results reported by Malechek and Leinweber (1972a) for Angora goats, and from those of Bryant et al. (1980) for Angora and Spanish goats in the Edwards Plateau of Texas. Increasing CP in diets of this study probably resulted from the constant and cumulative contribution of vines in the diet as seasons progressed. Saw greenbriar and principally southern dewberry leaves appeared to regrow rapidly even in late fall and winter when showers and mild temperatures occurred. Continuous regrowth of willow baccharis leaves throughout winter also helped to maintain dietary CP levels in this normally deficient period.

\section{Spring}

Differences in proportions to forage classes in diets from the untreated and mechanically treated pastures was minimal during the spring. However, goat diets from the tebuthiuron-treated pas- 
tures were higher in grasses, grasslikes and forbs and lower in browse content. Vines were similar in composition across treatments.

Browse occurred in the diets of goats during spring as: yaupon > oaks $>$ willow baccharis $>$ winged elm. However, when availability of browse was considered, then selection ranking for browse in the goats' diet was as follows: willow baccharis > winged elm $>$ yaupon > oaks. Selectivity of winged elm sprouts would be greater than willow baccharis when present.

$\mathrm{CP}$ content of diets in spring from untreated and mechanically treated pastures was similar and averaged 4 or more percentagc units less than that of diets from the tebuthiuron-treated areas. This difference in CP for the spring period was probably a result of higher amounts of forbs and succulent grasses and grasslike plants in diets from tebuthiuron-treated plots as compared with those from the other treatment pastures.

Dietary IVDOM was not different between the tebuthiurontreated and mechanically treated pastures during spring. Goat diets from the untreated pastures were lower in IVDOM during this same period when compared to those of the tebuthiurontreated and mechanically treated pastures. Careful review of the botanical composition of the diets from the mechanically treated pastures did not reveal any explanation for these differences. In fact, the species composition in the diets from the mechanically treated pastures would suggest IVDOM values more similar to those of the untreated pastures.

\section{Discussion}

Grass may become an important component of goat diets when browse availability is decreased (Rector and Huston 1982) or when the availability of high quality grasses and forbs is increased (Sidahmed et al. 1981). Comparison of these results with those reported by Malechek and Leinweber (1972b) and Bryant et al. (1979) in the live oak savannah of west Texas is somewhat difficult. Fundamental differences existed among physiognomic structures of the plant community of those trials and the present study. Moreover, goat grazing pressure was much reduced on the pastures during this study as compared with studies of Malechek and Leinweber (1972b) and Bryant et al. (1979). Despite these differences, some basic points of these trials were similar. For instance, during winter browse was high in diets, regardless of treatment. However, previous studies in live oak communities reported browse to be the most important class of dietary forage in summer and fall (Fraps and Cory 1940, McMahan 1964). Seasonal shifts in selection of grasses and browse in diets were also evident among other studies. A basic deviation occurred because animals could complement their diets with vines in this study. Forbs, especially during the spring, occurred less frequently in diets in this study as compared to those in the previously mentioned studies. This possibly could be due to the reduced diversity of forbs found in the Post Oak Savannah as compared to the Edwards Plateau of Texas.

Based on absolute plant values in dietary composition, goats have been described traditionally as browsers (Fraps and Cory 1940, Wilson 1957, McMahan 1964, Davis et al. 1975, Wilson et al. 1975, Fierro et al. 1977, and Sidahmed et al. 1981), grazers (Knight 1965 and Somlo et al. 1981), and animals that readily consume both grass and browse (Malechek and Leinweber 1972b, Nge'the and Box 1976, and Bryant et al. 1979). However, goat dietary selection assessed by the selectivity ratios tends to minimize extremes in their acceptability of a forage class or plant. In this study, vines were the forage class most highly preferred by goats, regardless of treatment or season (Table 2). Preference for forbs, grasses and grasslike plants, and browse was inversely associated with brush availability. Forbs, grasses and grasslike plants, in general, had high selection ratios on untreated and mechanically treated pastures, whereas browse was highly selected on the tebuthiuron-treated areas. Brush species with positive selection ratios on all pastures were willow baccharis, eastern redcedar, coralberry, and gum humelia. Depending on growth form, oaks, winged elm and yaupons were generally selected in proportion to their availability.

Because of the lack of a precise method of evaluation, current year's growth of woody vegetation was probably over-estimated, mainly on untreated and mechanically treated areas. Conversely, experimental procedures most likely underestimated the standing crop of saw greenbriar since these climbing vines are associated with tree trunks and may not have occurred in the sample plotframes. These factors possibly influenced the generally low preference values of browse species and the always highly positive preference for saw greenbriar. Still, goat preference for browse was less than expected.

Goat diets from the different brush-treated pastures apparently contained adequate levels of $\mathrm{CP}$ for maintenance and production (NRC 1981). However, during dry summers a CP for lactation deficiency could occur in all pastures, especially in tebuthiurontreated pastures where the herbaceous material is in advanced stage of maturity and brush kill is near complete.

Energy is potentially a limiting nutritive factor for Spanish goats grazing Post Oak Savannah rangelands. This conclusion is based upon nutritional requirement calculations for a $30-\mathrm{kg}$ meat-type nanny in early pregnancy under medium activity conditions (NRC 1981). The inadequacy of energy in goat diets is apparently an intrinsic characteristic of this range situation, especially in woodland situations during dry growing conditions. Malechek and Leinweber (1972a) on fair and good, and Bryant et al. (1980) on excellent condition rangelands, reported comparable energy shortages for goats in the Edwards Plateau of Texas.

\section{Management Implications}

In the Post Oak Savannah Region of Texas, yaupons, willow baccharis, and to some extent, saw greenbriar are serious range management problems which resist control by broadcast applications of herbicides (Scifres et al. 1981). Such troublesome species were the principal component of goat diets in this study. Overall, they usually occurred most consistently in animal diets across treatments and especially during winter when they formed the primary food of the goats. Vines, yaupon, and willow baccharis resprouted continuously after being grazed, even during the winter. Goats persistently used these species, regardless of treatment or season. Since these species keep resprouting, and subsequent defoliation by goats occurs over time, plant vigor would likely decrease. The final result would be a stand of woody plants with reduced competitive capability. Therefore, controlled goat use applied in this area especially during the winter and maintained through spring could potentially reduce these species, with no relevant harm to desirable range plants. This approach, if used as a followup practice to conventional methods of brush management, would increase efficiency in controlling these troublesome plants, thus sustaining the beneficial aspects of brush control methods with limited competition with cattle. An energy supplementation program would seem necessary for goats mainly during late gestation, if an overall high animal performance is desired in this region.

\section{Literature Cited}

AOAC. 1970. Methods of analysis, 117th ed. Ass. Official Agr. Chemists. Washington, D.C.

Barr, A.J., and J.H. Goodnight. 1979. A user's guide to the statistical analysis system. Sparks Press, Raleigh, N.C.

Bryant, F.C., M.M. Kothmann, and L.B. Merrill. 1979. Diets of sheep, Angora goats, Spanish goats, and whitetailed decr under excellent range conditions. J. Range Manage. 32:412-417.

Bryant, F.C., M.M. Kothmann, and L.B. Merrill. 1980. Nutritive content of sheep, goat, and white-tailed deer diets on excellent condition rangeland in Texas. J. Range Manage. 33:410-414.

Cottam, G., and J.T. Curtis. 1956. The use of distance measures in phytosociological sampling. Ecology 37:451-460. 


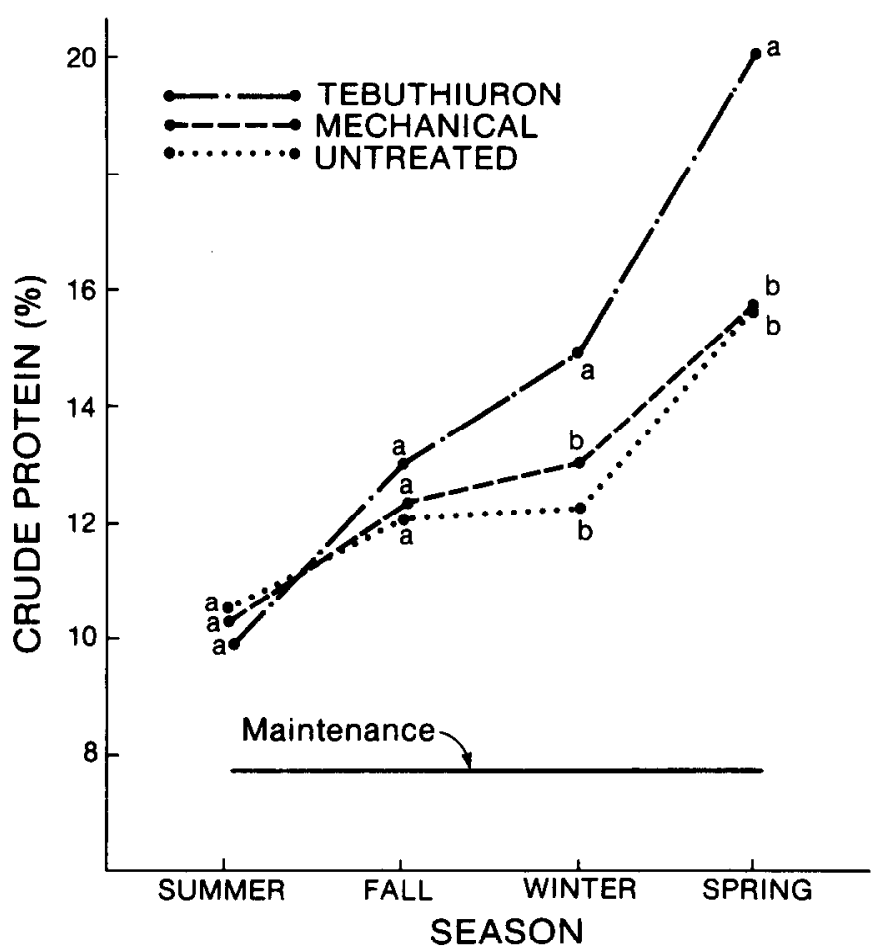

Fig. 2. Seasonal fluctuation in \% crude protein of Spanish goat diets, from summer 1980 through spring 1981 on untreated, mechanically treated and tebuthiuron-treated pastures in east central Texas. For each season, values with the same letter in a vertical direction are not significantly different $(\alpha=0.05)$. Maintenance requirement is based on a $30-k g$ female and medium activity (NRC 1981).

Davis, G.G., L.E. Bartel, and C.W. Cook. 1975. Control of Gambel oak sprouts by goats. J. Range Manage. 28:216218.

Fierro, L.C., F. Gomez, and M.H. Gonzales. 1977. Utilizacion de arbustivas indeseables por medio del pastoreo com cabras. Bol. Pastizales, RELC-INIP-SARH, Mexico. 8: 1-10.

Fierro, L.C., F. Gomez, and M.H. Gonzalez. 1980. Biological control of undesirable brush species with the use of goats in Northern Mexico. (Unpub. data).

Fraps, G.S., and V.L. Cory. 1940. Composition and utilization of range vegetation of Sutton and Edwards Counties. Tex. Agr. Exp. Sta. Bull. 586.

Green, L.R., C.L. Hughes, and W.L. Graves. 1978. Goat control of brush regrowth on southern California chaparral fuelbreaks. p. 451-455. In: Proc. First Internat. Rangeland Cong., Denver, Colo.

Hodgson, J. 1982. Influence of sward characteristics on diet selection and herbage intake by the grazing animal. p. 153-166. In: Nutritional limits to animal production from pastures. Commonwealth Agr. Bureau Slough SL2 3BN, UK.

Kirby, D.R., and J.W. Stuth. 1982^. Botanical composition of cattle diets during brush managed pastures in east-central Texas. J. Range Manage. 35:434-436.

Kirby, D.R., and J.W. Stuth. 1982b. Brush management influences the nutritive content of cattle diets in east-central Texas. J. Range Manage. $35: 431-433$.

Knight, J. 1965. Some observations on the feeding habits of goats in the South Baringo District of Kenya. East African Agr. and Forestry J. 30:182-188.

Kothmann, M.M., C.L. Leinweber, and L.B. Merrill. 1972. Nut rient content of the diet of range sheep. Proc: West. Sec. Amer. Soc. of Anim. Sci. 23:211-215.

Malechek, J.C., and C.L. Leinweber. 1972a. Chemical composition and in vitro digestibility of forage consumed by goats on lightly and heavily stocked ranges. J. Animal Sci. 35:1014-1019.

Malechek, J.C., and C.L. Leinweber. 1972b. Forage selectivity by goats on lightly and heavily grazed range. J. Range Manage. 25:105-107.

Martin, J.A., and D.L. Huss. 1981. Goats much maligned but necessary. Rangelands. 3:199-201.

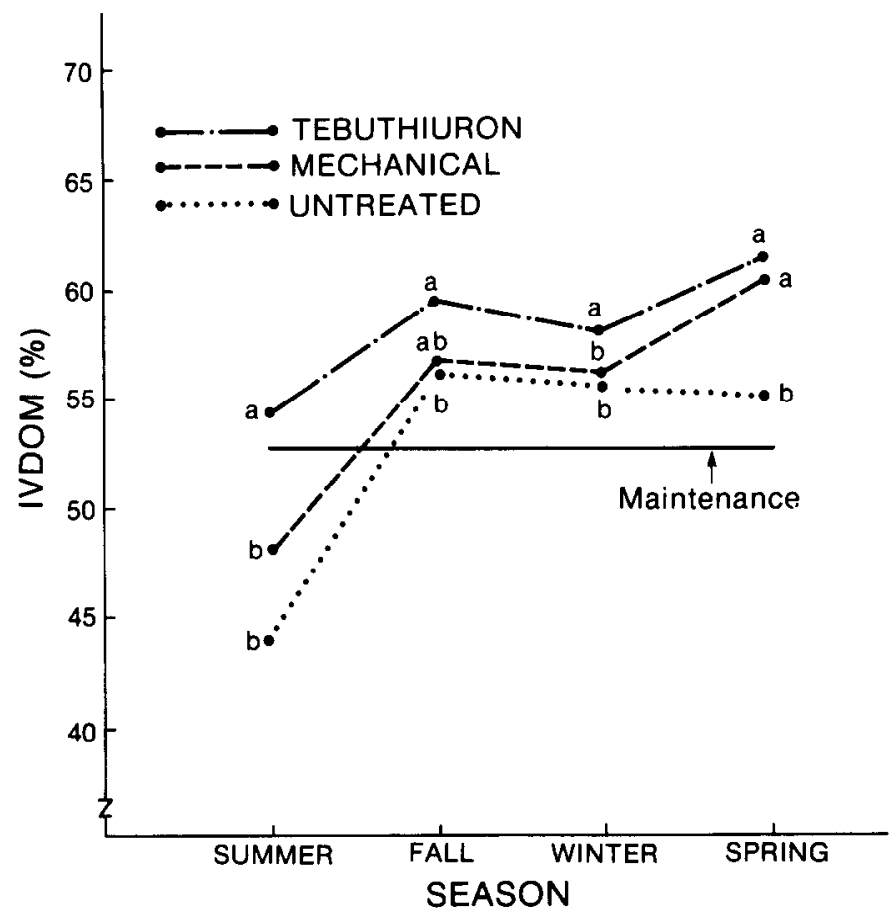

Fig. 3. Seasonal fluctuation in $\%$ in vitro digestible organic matter of Spanish goat diets, from summer 1980 through spring 1981 on untreated, mechanically treated and tebuthiuron-treated pastures in east-central Texas. For each season, values with the same letter in a vertical direction are not significantly different $(\alpha=0.05)$. Maintenance requirement is based on a $30 \mathrm{~kg}$ female and medium activity (NRC 1981).

McMahan, C.A. 1964. Comparative food habits of deer and three classes of livestock. J. Wildlife Manage. 28:798-808.

Nge'the, J.C. and Thadis W. Box 1976. Botanical composition of eland and goat on an acacia-grassland community in Kenya. J. Range Manage. 29:290-293.

NRC. 1981. Nutrient requirements of domestic animals; No. 15, Nutrient requirements of goats. Nat. Acad.f Sci., Washington, D.C.

Rector, B.S., and J.E. Huston. 1982. Composition of diets selected by livestock grazing in combination. p. 320. In: Abstracts of Papers, 1982, Joint Meet. Amer. Soc. Anim. Sci. and Canad. Soc. Anim. Sci., Guelph, Ont., Canada.

Scifres, C.J. 1980. Brush Management. Texas A\&M University Press. College Station.

Scifres, C.J., and R.H. Haas. 1974. Vegetation changes in a Post Oak Savannah following plant control. Texas Agr. Exp. Sta. MP 1136.

Scifres, C.J., M.M. Kothmann, and G.W. Mathis. 1974. Range site and grazing system influence regrowth after spraying honey mesquite. J. Range Manage. 29:97-100.

Scifres, C.J., J.W. Stuth, and R.W. Bovey. 1981. Control of oaks (Quercus spp.) and associated woody species on rangeland with tebuthiuron. Weed Sci. 29:270-275.

Sidahmed, A.E., J.G. Morris, and S.R. Radosevich. 1981. Summer diet of Spanish goats grazing chaparral. J. Range Manage. 34:33-35.

Smeins, F.E., and R.D. Slack. 1978. Fundamentals of ecology. Kendall/Hunt Publ., Dubuque, lowa.

Somlo, R., G. Campbell, and A. Pelliza-Sbriller. 1981. Study of the dietary habits of Angora goats in rangelands in Patagonia. p. 525-544. In: Proc. Internat. Symposium on Nutrition and Systems of Goat Feeding (Vol. 2). 
Steel, Robert G.D., and J.H. Torrie. 1980. Principles and procedures of statistics. McGraw-Hill, New York.

Tilley, J.A., and R.A. Terry. 1963. A two-stage technique for the in vitro digestion of forage crop. J. Brit. Grass. Soc. 18:104-111.

Taylor, C.A., M.M. Kothmann, L.B. Merrill, and D. Elledge. 1980. Diet selection by cattle under high-intensity, low-frequency, short duration and Merrill grazing systems. J. Range Manage. 33:428-434.

Taylor, C.A., and F.C. Bryant. 1977. A durable esophageal cannula for sheep and goats. J. Range Manage. 30:397-398.

Ueckert, D.N. 1980. Manipulating range vegetation with prescribed burning. p. 27-44. Proc. Symposium on Prescribed Range Burning in the Edwards Plateau of Texas.
U.S. Department of Commerce. 1975. National Oceanic and Atmospheric Administration Climatological Data for Texas.

Van Dyne, G.N., and D.T. Torrel. 1964. Development and use of the esophageal fistula: A review. J. Range Manage. 17:7-19.

Van Soest, P.J., and R.H. Wine. 1967. Use of detergents in the analysis of fibrous feeds. IV. Determinations of plant and plant cell-wall constituents. J. Ass. Off. Agr. Chemists. 50:50-55.

Wilson, A.D., J.H. Leight, N.L. Hindley, and W.E. Mulham. 1975.Companison of diets of goatsandsheepona Casuarinacristata-Heteroderutnom oleifolium woodland community in Western New South Wales. Aust. J. Exp. Agr. and Anim. Husb. 15:45-53.

Wilson, P.M. 1957. Studies of the browsing and reproductive behavior of the East African dwarf goat. East African Agr. J. 23:138-148. 